\title{
Spectrum of tumors in the families with Hereditary Breast Ovarian Cancer syndrome carrying germline mutations in BRCA1 and 2 genes
}

M Budryk ${ }^{1 *}$, J Pamuła-Piłat ${ }^{2}$, K Tęcza², E Grzybowska²

From Annual Conference on Hereditary Cancers 2010

Szczecin, Poland. 10-11 December 2010

The aim of genetic tests performed by Genetic Counseling at Centre of Oncology was to screen for carriers of germline mutations in BRCA1 and 2 genes who are at high risk of developing breast or/and ovarian cancer.

Among the patients qualified to genetic tests there are the patients who do not meet the Amsterdam criteria of HBOC syndrome.

In Genetic Counseling at Centre of Oncology we find germline mutations in BRCA1 and 2 genes in about 5\% of patients. Beginning in January 2003 until now we found mutations in BRCA genes in 247 families. Not all families belong to the group of high risk of developing breast or ovarian cancer. Among them there were 23 families which did not meet pedigree and clinical criteria.

Analysis of tumors which were developed by the members of families carrying germline mutations in BRCA1/2 genes revealed mainly breast (415) and ovarian (170) cancers. There were also tumors which were not typical for this mutation. The most frequent not typical tumors in the families with germline BRCA1/2 mutations were: lung cancer (38), intestinal tract tumors (26) - including stomach cancer, liver cancer (20), pancreas cancer (15) and also hematopoietic tumors among them leukemias (17), prostate cancer (14) and other.

These findings justify performing genetic tests for germline mutations in BRCA1/2 genes not only for the

\footnotetext{
* Correspondence: magda.budryk@op.pl

${ }^{1}$ Genetic Counseling In Outpatient Clinics, Maria Skłodowska-Curie Memorial

Cancer Center and Institute of Oncology, Gliwice Branch, Poland

Full list of author information is available at the end of the article
}

patients who meet pedigree and clinical criteria typical for HBOC syndrome.

\section{Author details}

'Genetic Counseling In Outpatient Clinics, Maria Skłodowska-Curie Memorial Cancer Center and Institute of Oncology, Gliwice Branch, Poland. ${ }^{2}$ Center for Translational Research and Molecular Biology of Cancer, Maria SkłodowskaCurie Memorial Cancer Center and Institute of Oncology, Gliwice Branch, Poland.

Published: 12 January 2012

\section{doi:10.1186/1897-4287-10-S1-A2}

Cite this article as: Budryk et al:: Spectrum of tumors in the families with Hereditary Breast Ovarian Cancer syndrome carrying germline mutations in BRCA1 and 2 genes. Hereditary Cancer in Clinical Practice 2012 10(Suppl 1):A2.

Submit your next manuscript to BioMed Central and take full advantage of:

- Convenient online submission

- Thorough peer review

- No space constraints or color figure charges

- Immediate publication on acceptance

- Inclusion in PubMed, CAS, Scopus and Google Scholar

- Research which is freely available for redistribution

Submit your manuscript at www.biomedcentral.com/submit C Biomed Central 